\title{
Dimensions of Regional Inequalities in Ghana: Assessing Disparities in the Distribution of Basic Infrastructure among Northern and \\ Southern Districts
}

\author{
Mark M. Akrofi \\ Master Student, Pan African University, Institute of Water and Energy Sciences incl \\ Cimate Change. c/o Tlemcen University, B.P. 119 \\ Pôle Chetouane, Tlemcen 13000 \\ Algeria \\ Bernard A. A. Akanbang \\ Senior Lecturer, Department of Planning, Faculty of Planning and Land Management \\ University for Development Studies \\ University Post Wa 3 \\ Ghana \\ Clement K. Abdallah \\ Master Student, Pan African University, Institute of Water and Energy Sciences incl \\ Cimate Change. c/o Tlemcen University, B.P. 119 \\ Pôle Chetouane, Tlemcen 13000
}

Algeria

Received: December 14, 2017 Accepted: January 23, 2018 Published: January 29, 2018

doi:10.5296/ijrd.v5i1.12293 URL: http://dx.doi.org/10.5296/ijrd.v5i1.12293

\begin{abstract}
Researches on regional inequalities in Ghana have largely focused on principal cities and towns as well as urban and rural areas. Based on the traditional north-south divide in Ghana, this study explored a third dimension of regional disparities, by assessing the level of infrastructural inequalities among districts in northern and southern Ghana. The study is based on a documentary review of existing statistics on the availability of basic infrastructure
\end{abstract}


in the selected districts. Twelve districts (2 each from 3 regions in the north and south respectively) were involved. The Composite Infrastructure Index (CII) method, Lorenz Curve and Gini Coefficient techniques were employed. Results showed that, the distribution of basic infrastructure among all twelve districts was skewed towards perfect equality (Gini coefficient $=0.20$ ). Inequalities were however more significant among districts of the north (Gini coefficient $=0.22$ ) than districts of the south (Gini coefficient $=0.12$ ). Albeit positive, no significant correlation was found between CIIs and population $(\mathrm{P}<.001)$ as well as Internally Generated Funds $(\mathrm{P}<.001)$ of the districts. The study also revealed that, on the average, districts allocated $97.1 \%$ of their Internally Generated Funds to administrative costs rather than infrastructure projects.

Keywords: Regional Inequalities, Basic Infrastructure, Decentralization, Districts, Ghana.

\section{Introduction}

A significant challenge facing governments of many developing countries, especially in sub-Saharan Africa is regional disparities in the provision and distribution of social services across regions (Poku-Boansi \& Amoako, 2015). Lall and Chakravorty (2004), defined regional inequality as a condition in which different spatial or geographical units are at different levels on some variable of interest, usually (average) income. Aryeetey et al. (2009), also defined it as the uneven distribution of social and economic indicators of human well-being within or among geographical units such as countries, cities, rural/urban areas, and regions. The United Nations Human Settlements Programme (UN-HABITAT, 2008b) traces the origin of spatial inequalities in African countries to their colonial past, but these inequalities are, however reinforced by post-colonial institutions which are characterised by flimsy and ineffective local governments, poor governance and corruption. From a theoretical perspective, Kim (2008), argues that, generally, spatial inequality is the net result of the balance of forces of concentration and dispersion. Escobal and Torero (2005), cite an example where inequalities between regions arise due to location and landscape features shaping the distribution of infrastructure and public goods. Kim (2008) further states that, regional inequality is primarily determined by the location decisions of the state. This assertion reflects the status quo in many African countries where most decisions concerning location and distribution of infrastructure and investments are led by the state and responded to by individuals, households and businesses (Poku-Boansi \& Amoako, 2015).

Songsore (1989) attributes spatial inequalities in Ghana to colonial dependency as the root cause. He argued that, Ghana was developed as a satellite nation to export food and raw materials to Britain during the colonial era. This resulted in the pursuit of different policies in the north and the south, which ensured that the north was a labor reserve for the southern economy. According to Songsore (1989), the net outcome of this was a distortion in the internal patterns of production, and the spatial organization of economic and social activity resulting from dependency and capitalist penetration, which under both colonialism and neo-colonialism shaped the internal structure to fit the needs of the colonial metropolis. Songsore's argument forms the basis of several studies conducted on regional inequality in Ghana. Adu-Brenya (1999), for instance, notes that due to the historical origin of spatial 
inequality which can be traced to the colonial era, spatial inequality in Ghana has often been viewed in terms of the 'north-south' divide and in terms of the 'urban-rural' divide. Several studies (e.g. Poku-Boansi \& Amoako, 2015; Ayeetey et al, 2009; World Bank, 2006; Chikata $\&$ Wayo, 2004) undertaken on spatial inequality in Ghana have been along this line.

As part of efforts to address these spatial disparities in Ghana, various policies were adopted by past and present governments to overcome the problem. One of such important policies was the decentralization policy of 1988. This policy has been in force since 1988 and continues to be the basic principle underpinning policy formulation, planning, infrastructure and social services provisioning in Ghana. Its principal objective is to ensure equitable distribution of the fruits of development and thus address regional imbalances. In line with this, the original 65 districts that existed by then were split into 110 and each given the power, means and competence to develop their areas. The districts were thus seen as a means of bridging regional disparities in Ghana, with District Assemblies tasked with the responsibility of integrating political, administrative and development support needed to achieve a more equitable allocation of power, wealth and geographically dispersed development in Ghana. This brings to bear another dimension to which spatial inequality can be viewed-inequalities among districts in Ghana. This dimension has, however received very little attention from both policy makers and planners in Ghana. Adu-Brenya (1999), for instance, noted that whiles the first two dimensions of spatial disparities (north-south and urban-rural) have received significant attention from planners and policy makers, not much attention has been paid to the disparities within the regions.

The role of decentralization in regional inequalities is one issue that has received significant attention in academic literature and public debate. Oates (1972), argued that, decentralization enhances public sector efficiency. On the other hand, Prud'homme (1995), asserts that decentralization can weaken inter-jurisdictional redistribution causing a rise in regional inequality. According to Lessmann (2011), this is the major argument still undergoing discussion in both public debate and academic literature. He adds that, a conflict between efficiency and redistribution might therefore arise from decentralization (Lessmann, 2011). With the increasing efforts towards public sector decentralization especially in developing countries, this is an important question for many governments around the world. Whiles concentrating resources and investments in some key regions can lead to polarization and hence spatial inequalities, distributing such resources and investments, especially through the creation of smaller administrative units as is the case in Ghana, might also result in inefficiencies by spreading resources too thin. More districts are being created with the objective of spreading the benefits of development equitably in Ghana. However, little can be said as to whether this objective is being realised due to the absence of studies of this sort. Attempts at establishing the inequality levels among the districts in Ghana (e.g Ghana poverty mapping by the Ghana Statistical Service (GSS), 2015) have also largely focused on income leaving other important dimensions such as infrastructure.

The above discussions provide the basis for this paper. The study explores regional inequalities in terms of availability of certain basic infrastructural facilities among some selected districts in northern and southern Ghana. It aims at establishing the nature of 
inequalities among the districts with regards to the availability of basic infrastructure related to education, health, water and sanitation, and power supply (electricity). The study also examines whether there is a significant relationship between the populations of districts, their ability to generate funds internally and the distribution of basic infrastructure among them.

\section{Materials and Methods}

\subsection{Methods and Data Sources}

The Composite Infrastructure Index approach was principally applied in this study. The method used by Alam (2011), in developing Composite Infrastructure Indices (CII) for some selected Indian states was adopted in computing infrastructure indices for the various districts under study (see calculation section below). After computing the CIIs for the districts, the Lorenz curve and Gini coefficient technique were used to analyze and present the infrastructural disparities between and among the districts of the north and south. The Gini co-efficient analytic is the most commonly used means of assessing inequalities in terms of income, provision and distribution of socioeconomic facilities (UN-HABITAT, 2008b). Ideally the Gini ratio is expressed as an index or a percentage. As an index, the Gini ratio ranges between 0 and 1; while as a percentage it ranges between 0 and $100 \%$. There is perfect equality among districts when the Gini co-efficient is zero and perfect inequality when it is 1 or $100 \%$. Therefore, the closer the Gini co-efficient is to 0 , the more equal a region is and the closer it is to $1(100 \%)$, the more unequal the region is (Poku-Boansi \& Amoako, 2015). The CIIs were also correlated against the populations and Internally Generated Funds (IGF) of each district in order to ascertain whether there is a significant relationship between them.

In all, twelve (12) districts were involved. Six administrative regions (three in the north and south respectively) were purposively selected based on their geographical locations. The regions are; Northern, Upper East and Upper West regions in the northern sector, and Central, Western and Ashanti Regions in the southern sector. Two districts each, were selected from these regions. Districts created in the year 2004 were considered for the study in order to ensure that there are no variations in the times of creation as this could influence the level of infrastructure within a district. Hence, from a time perspective and all things being equal, the selected districts should be on some equal level of infrastructural development. However, the selection of individual districts was principally based on the availability of data on the selected indicators in the 2014-2017 Medium-Term Development Plans (MTDPs) of the districts, their 2015 Composite budgets and 2010 population and housing census district analytic reports. With regards to this, two districts created in 2008 (one in the north and south respectively) were involved due to the difficulty in obtaining data on the selected indicators for some districts created in 2004. Indicators for the four sectors of infrastructure selected for this study are presented below. 
Table 1. Education infrastructure indicators

\section{DISTRICT INDICATORS}

\begin{tabular}{|c|c|c|c|c|c|}
\hline & $\begin{array}{l}\text { KG \& } \\
\text { Primary } \\
\text { schools }\end{array}$ & $\begin{array}{l}\text { Junior } \\
\text { High } \\
\text { Schools }\end{array}$ & $\begin{array}{l}\text { Senior } \\
\text { High/Technical } \\
\text { and vocational } \\
\text { schools }\end{array}$ & $\begin{array}{l}\text { High } \\
\text { Education } \\
\text { institutions }\end{array}$ & $\begin{array}{l}\text { Toatal No. } \\
\text { of Teachers } \\
\text { in basic } \\
\text { sch. }\end{array}$ \\
\hline Adansi South & 101 & 55 & 4 & 0 & 1318 \\
\hline Atwima Mponua & 282 & 77 & 3 & 0 & 1373 \\
\hline Gomoa west & 183 & 79 & 8 & 0 & 1451 \\
\hline $\begin{array}{l}\text { Upper Denkyira } \\
\text { West }\end{array}$ & 116 & 37 & 2 & 0 & 861 \\
\hline Amenfi Central & 231 & 63 & 1 & 0 & 951 \\
\hline $\begin{array}{l}\text { Sefwi } \\
\text { Akontombra }\end{array}$ & 151 & 28 & 1 & 0 & 432 \\
\hline Kpandai & 139 & 19 & 1 & 0 & 267 \\
\hline $\begin{array}{l}\text { Sawla-Tuna-Kalb } \\
\text { a }\end{array}$ & 155 & 33 & 4 & 0 & 776 \\
\hline Talensi & 92 & 28 & 2 & 0 & 712 \\
\hline Nabdam & 46 & 15 & 0 & 0 & 359 \\
\hline Wa West & 145 & 51 & 0 & 0 & 681 \\
\hline Sissala East & 109 & 46 & 3 & 1 & 562 \\
\hline
\end{tabular}

Sourced from DMTDPs and District Population Census Analytic Reports 
Table 2. Health infrastructure indicators

\begin{tabular}{|c|c|c|c|c|c|}
\hline \multirow[t]{2}{*}{ DISTRICT } & \multicolumn{5}{|l|}{ INDICATORS } \\
\hline & $\begin{array}{l}\text { Community Health } \\
\text { Planning and Services } \\
\text { (CHPS) }\end{array}$ & $\begin{array}{l}\text { Maternity } \\
\text { Homes }\end{array}$ & $\begin{array}{l}\text { Health } \\
\text { Centers }\end{array}$ & $\begin{array}{l}\text { Polyclinic/ } \\
\text { Clinics }\end{array}$ & Hospital \\
\hline Adansi South & 7 & 1 & 4 & 0 & 1 \\
\hline Atwima Mponua & 3 & 3 & 6 & 1 & 1 \\
\hline Gomoa west & 17 & 1 & 5 & 2 & 1 \\
\hline Upper Denkyira & 7 & 0 & 3 & 4 & 0 \\
\hline Amenfi Central & 7 & 0 & 2 & 3 & 0 \\
\hline Sefwi Akontombra & 15 & 1 & 3 & 2 & 0 \\
\hline Kpandai & 0 & 0 & 2 & 7 & 2 \\
\hline Sawla-Tuna-Kalba & 8 & 0 & 0 & 4 & 0 \\
\hline Talensi & 14 & 0 & 2 & 2 & 0 \\
\hline Nabdam & 2 & 0 & 1 & 3 & 0 \\
\hline Wa West & 16 & 2 & 5 & 0 & 0 \\
\hline Sissala East & 9 & 1 & 6 & 1 & 1 \\
\hline
\end{tabular}

Sourced from DMTDPs and District Population Census Analytic Reports 
Table 3. Water and sanitation infrastructure indicators

DISTRICT INDICATORS (\% of households)

$\begin{array}{llllll}\text { Borehole/Pump/ } & \text { Stand } & \text { Pipe } & \text { Public } & \text { Public } & \text { Sewerage } \\ \text { Tubewell } & \text { pipe/Public } & \text { borne } & \text { Toilets } & \begin{array}{l}\text { dump } \\ \text { (refuse }\end{array} & \text { system } \\ & \text { Tap } & & & \text { skip) } & \\ & & & & & \end{array}$

\begin{tabular}{|c|c|c|c|c|c|c|}
\hline Adansi South & 50.8 & 6.5 & 5.0 & 51.6 & 10.9 & 1.4 \\
\hline Atwima Mponua & 55.2 & 10.4 & 10.3 & 53.9 & 2.8 & 1.0 \\
\hline Gomoa west & 8.0 & 17.2 & 22.1 & 34.2 & 6.3 & 0.9 \\
\hline Upper Denkyira & 42.3 & 25.1 & 14.7 & 52.2 & 11.9 & 0.7 \\
\hline Amenfi Central & 18.3 & 9.3 & 10.1 & 37.3 & 1.7 & 0.8 \\
\hline $\begin{array}{l}\text { Sefwi } \\
\text { Akontombra }\end{array}$ & 25.0 & 4.6 & 7.1 & 30.2 & 2.8 & 0.7 \\
\hline Kpandai & 24.6 & 16.1 & 11.0 & 10.5 & 8.4 & 2.7 \\
\hline Sawla-Tuna-Kalba & 61.5 & 5.8 & 1.7 & 4.3 & 4.7 & 1.4 \\
\hline Talensi & 64.8 & 0.5 & 4.8 & 1.2 & 0.6 & 4.0 \\
\hline Nabdam & 72.6 & 1.5 & 5.9 & 0.9 & 2.0 & 3.6 \\
\hline Wa West & 79.3 & 0.9 & 3.6 & 3.1 & 3.2 & 0.7 \\
\hline Sissala East & 71.6 & 2.7 & 20.9 & 8.5 & 7.1 & 1.6 \\
\hline
\end{tabular}

Sourced from DMTDPs and District Population Census Analytic Reports 
Table 4. Power supply infrastructure indicators

DISTRICT

\section{INDICATORS (\% of households)}

$\begin{array}{llll}\text { Electricity } & \text { Electricity } & \text { Solar (urban) } & \text { Solar (rural) } \\ \text { Nat Grid (urban) } & \text { Nat Grid (rural) } & & \end{array}$

\begin{tabular}{|c|c|c|c|c|}
\hline Adansi South & 77.0 & 17.9 & 0.1 & 0.9 \\
\hline Atwima Mponua & 82.1 & 19.2 & 0.1 & 0.2 \\
\hline Gomoa west & 70.4 & 69.8 & 0 & 0 \\
\hline $\begin{array}{l}\text { Upper Denkyira } \\
\text { West }\end{array}$ & 0.0 & 56.9 & 0 & 0.4 \\
\hline Amenfi Central & 75.5 & 36.3 & 0.2 & 0.3 \\
\hline Sefwi Akontombra & 76.4 & 16.8 & 0 & 0.4 \\
\hline Kpandai & 73.9 & 24.0 & 0.4 & 0.2 \\
\hline Sawla-Tuna-Kalba & 65.7 & 4.2 & 0.4 & 0.2 \\
\hline Talensi & 8.2 & 6.9 & 0.1 & 0.5 \\
\hline Nabdam & 0.0 & 8.6 & 0.0 & 0.2 \\
\hline Wa West & 0.0 & 9.5 & 0.0 & 0.5 \\
\hline Sissala East & 82.3 & 19.8 & 0.3 & 3.7 \\
\hline
\end{tabular}

Sourced from DMTDPs and District Population Census Analytic Reports

Data on the above indicators and the entire study were mainly obtained from secondary sources. These include the DMTPs, composite budgets and 2010 population and housing census district analytic reports. The study is thus based on a documentary review of existing statistics on the availability of basic infrastructure in the selected districts.

\subsection{Calculation}

Computing the CIIs includes three steps. In the first step, different sets of indicators were used for each of the four sectors of infrastructure, namely; education, health, water and sanitation, and power supply. Each of these indicators or parameters selected for an 
infrastructure sector was defined as a dimension with the value between 0 and 1 with reference to the maximum and the minimum values among them. The general formula for calculating dimension value is transformed by using an equation of the form:

$$
\text { Dimension Value }=\frac{\text { Actual Value }- \text { Minlmum value }}{\text { Maximum value }- \text { Minlmum Value }}
$$

In other words, if $\mathrm{X}_{\mathrm{ij}}$ represents the value of the $\mathrm{i}^{\text {th }}$ infrastructure indicator in $\mathrm{j}^{\text {th }} \operatorname{district}(\mathrm{j}=1,2$, 3....12.), then the dimension value can be calculated as:

$$
\frac{\underline{X}_{i j}-\underline{\operatorname{Min}}_{i} \underline{X}_{i j}}{\operatorname{Max}_{j} X_{i j}-\operatorname{Min}_{j} X_{i j}}
$$

Where, $\operatorname{Min}_{\mathrm{j}} \mathrm{X}_{\mathrm{ij}}$ and $\operatorname{Max}_{\mathrm{j}} \mathrm{X}_{\mathrm{ij}}$ are the minimum and maximum of $\mathrm{Xij}$ respectively. This was used to calculate the dimension values for all indicators covering the four sectors of physical infrastructure selected.

In the second step, following the practice adopted in the calculation of the Human Development Index (HDI) as used by Alam (2011), a simple arithmetic mean of the dimension values of the selected indicators of the infrastructure sectors was taken for each district to construct Composite Dimension Index (CDI). The districts were then ranked on the basis of the CDI from the lowest to highest. That is, lowest rank has been given to the district which has the minimum CDI and highest rank to the district having the maximum of it. Lowest rank means lowest rank numeral whiles highest rank means highest rank numeral. Hence, among the twelve districts selected for the study, the district with the lowest CDI is ranked as 1 whiles the district with the highest CDI is ranked as 12 .

In the final step, a simple arithmetic mean of the rank of CDI of all the four sectors selected for each district was taken to arrive at the Composite Infrastructure Index (CII). This is given by the formula:

$$
C H=\sum_{t=1}^{n=4} \mathrm{VR} / \mathrm{N}
$$

Where, $\mathrm{CII}=$ Composite Infrastructure Index,

$\mathrm{n}=$ total number of infrastructure sectors selected for the study,

$\mathrm{VR}=$ rank of variable $\mathrm{i}$,

$\mathrm{i}=$ Composite dimension index

$\mathrm{N}=$ Total number of indicators

In illustrating inequalities among the districts using the Lorenz curve and Gini coefficient techniques, the average of CDIs of each district across all four sectors of basic infrastructure were used rather than the CIIs computed in the last step above. This is due to the fact that the 
final CII computed in the last step as used by Alam (2011) is based on an arithmetic mean of the ranks of the districts across the sectors. Lorenz curve based on the CIIs will thus say more about the ranking of districts across the sectors rather than the dimension of inequalities between the districts. Hence, CDIs of each district for each sector were summed up respectively and divided by four (the number of sectors) to arrive at average CDIs which were used in in drawing the Lorenz curves and computing the Gini coefficients.

\section{Results}

\subsection{Populations of the Study Districts}

Infrastructure provision is influenced by population size. As such, planners at various districts in Ghana have been provided with planning standards which guide them in doing infrastructural needs assessments for their districts. The Planning standards detail out the threshold populations as well as the technical specifications required for the provision of basic infrastructure services including educational, health, water and sanitation facilities. As noted by Poku-Boansi and Amoako (2015), since infrastructure provision is influenced by population size, it implies that, districts with larger populations will enjoy the largest share of investment in infrastructure and services. It can thus be presumed from table 1 that districts in the South will have larger share of investments in infrastructure and hence higher infrastructure indices than districts in the North since they are generally more populated than the districts in the north. As computed from table 1, the average population of a district in the South is 96,880 as compared to an average of 81,794 in the North.

Table 5. Populations of the Study Districts

\begin{tabular}{llll}
\hline SECTION & REGION & DISTRICT & POPULATION \\
\hline Ashanti & Adansi South & 115,378 \\
SOUTH & Atwima Mponua & 119,180 \\
& & Gomoa west & 135,189 \\
& Western Region & Upper Denkyira West & 60,054 \\
& & Amenfi Central & 69,014 \\
& Northern & Sefwi Akontombra & 82,467 \\
& & Kpandai & 108,816 \\
& & Sawla-Tuna-Kalba & 99,863 \\
& & Talensi & 81,194 \\
\hline
\end{tabular}




$\begin{array}{llr} & \text { Nabdam } & 63,014 \\ \text { Upper west } & \text { Wa West } & 81,348\end{array}$

Sissala East

56,528

Sourced from 2010 population and housing census district analytic reports.

\subsection{Distribution of Basic Infrastructure Among all Districts}

Composite Infrastructure Indices of the various districts revealed significant disparities in the availability of basic infrastructure among them. The highest CII was 10.5 whiles the lowest was 2.25. Sissala East District in the Upper West Region and Nabdam District in the Upper East Region recorded these indices respectively. Both districts are found in the Northern sector of the country. In the southern sector, the highest CII was 10.25 whiles the lowest was 4.25. (see table 6).

Table 6. Composite Infrastructure Indices of the Districts

\begin{tabular}{|c|c|c|c|}
\hline SECTOR & REGION & DISTRICT & CII \\
\hline \multirow{5}{*}{ SOUTH } & Ashanti & Adansi South & 8.25 \\
\hline & & Atwima Mponua & 8.75 \\
\hline & Central & Gomoa west & 10.25 \\
\hline & & Upper Denkyira West & 6.75 \\
\hline & Western & Amenfi Central & 6.25 \\
\hline \multirow{7}{*}{ NORTH } & & Sefwi Akontombra & 4.25 \\
\hline & Northern & Kpandai & 7.5 \\
\hline & & Sawla-Tuna-Kalba & 5.00 \\
\hline & Upper East & Talensi & 4.00 \\
\hline & & Nabdam & 2.25 \\
\hline & Upper west & Wa West & 4.25 \\
\hline & & Sissala East & 10.5 \\
\hline
\end{tabular}




\section{Macrothink}

Authors Own Construct, 2017

The Lozenze curve and Gini coefficient as seen in figure 1 below illustrates that, even though inequalities exist among all districts, the distribution of basic infrastructure among them is skewed towards perfect equality with a Gini coefficient of .20 which is closer to zero (perfect equality) than one (perfect inequality).

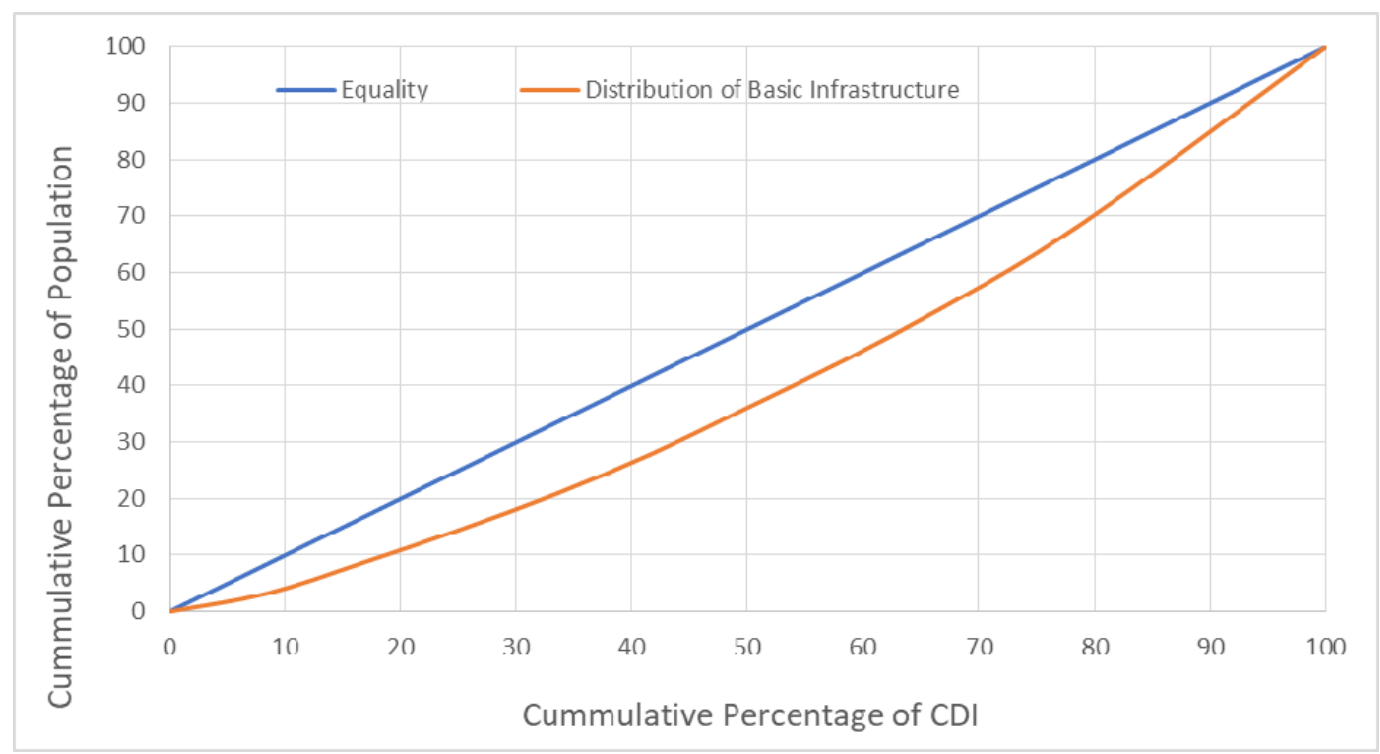

Figure 1. Distribution of Basic Infrastructure among All Districts (Gini Coefficient $=0.20)$

(Author's Own Construct, 2017)

\subsection{Distribution of Basic Infrastructure among Northern and Southern Districts}

The study revealed that, in both northern and southern Ghana, the distribution of basic infrastructure among districts is closer to a more even distribution than an uneven distribution. However, distribution of basic infrastructure among districts of the south is skewed towards perfect equality than districts in the north. With a Gini Coefficient of .12, there is an almost equal distribution of basic infrastructure among districts of the South than districts of the North which have a Gini Coefficient of .22. This finding reflects that of Poku-Boansi and Amoako (2015) who realised that, inequalities in access to basic facilities and services in major Ghanaian cities are more significant among cities of the north than cities of the south. They attributed this to past colonial policies and the concentration of bulk of Ghana's natural resources in the southern part of the country. Distribution of basic infrastructure among districts in the two sectors are presented in figure 2 and 3 below. 


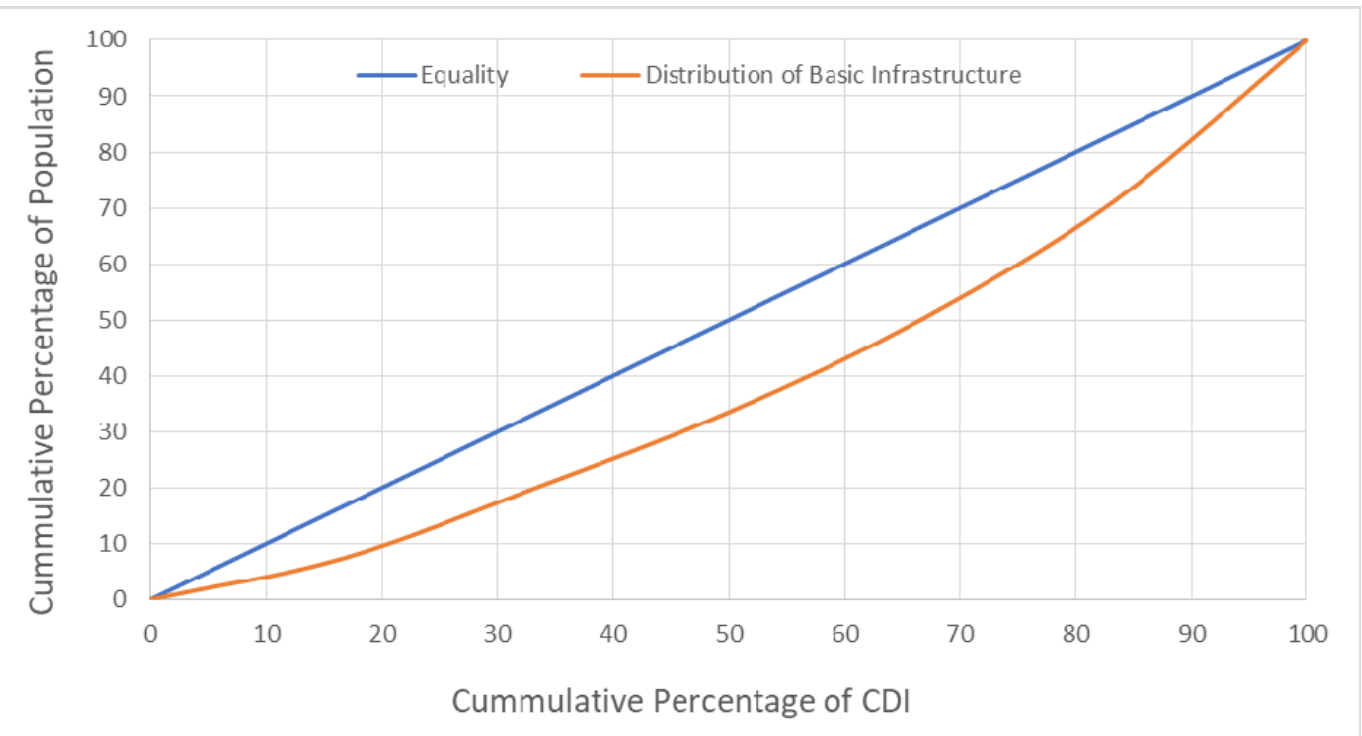

Figure 2. Distribution of Basic Infrastructure among Northern Districts (Gini Coefficient $=$ $0.22)$

(Author's Own Construct, 2017)

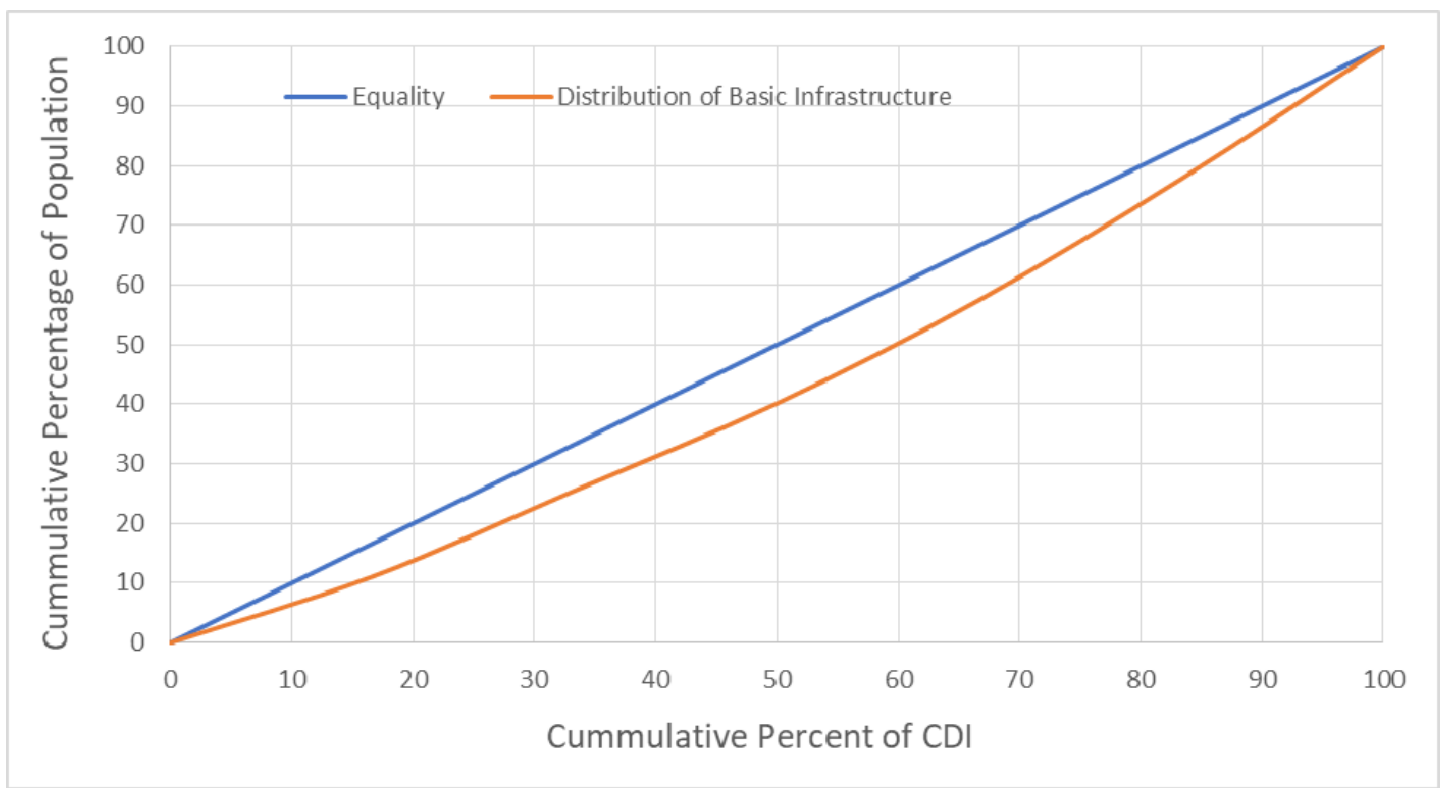

Figure 3. Distribution of Basic Infrastructure among Southern Districts (Gini Coefficient $=$ $0.12)$

(Author's Own Construct, 2017)

\subsection{Relationship between Population and Infrastructure Availability in the Districts}

Studies have shown that there is a two-way relationship between population and infrastructure. Some authors argue that, infrastructure provision is influenced by population (Poku-Boansi \& Amoako, 2015) hence an increase in population requires an expanded or enhanced infrastructure and services (Asoka et. al, 2013), others argue that, infrastructure 


\section{Macrothink}

availability attracts population into a particular locality and hence leads to an increase in population (Pradhan, 2007; Tiebout, 1956). Either way, what is common to both perspectives is that, localities with higher infrastructure availability are expected to be associated with higher populations and vice-versa. Hence whether infrastructure influences population or population influences infrastructure provision, one would expect that districts with high populations would have higher infrastructure indices and vice-versa.

Deduced from tables 5 and 6, it could be seen that, with an average population of 96,880 , districts of the South have an average CII of 7.4 whiles districts in the North have and average CII of 5.6 with an average population of 81,794 . In this regard, the above assertion that districts with higher populations are associated with higher infrastructure can be said to be true. A 2-tailed Pearson correlation between population and CII however revealed that, even though there is a positive correlation (correlation coefficient $=.428$ ) between population and infrastructure, this relationship is insignificant with a $P$ value greater than $.01(P=.165)$.

\subsection{Internally Generated Funds (IGF) and Infrastructure Availability Among Districts}

One key source from which districts finance the implementation of their MTDPs is through Internally Generated Funds (IGF). These are funds principally generated within the jurisdiction of each district usually from fines, licenses, fees, rents, land, investments among others. Unlike the District Assembly Common Fund (DACF) which is allocated by the central government with some approved formula to the districts, the IGF is dependent on the districts own ability to mobilise revenue from within its jurisdiction. From the various sources that this fund is generated as indicated earlier, it implies that districts with more assets, taxable items, investments among others would be able to generate more revenue for funding their projects. Table 7 shows the IGF of the various districts as of June, 2014. 
Table 7. Internally Generated Funds of the Various Districts

\begin{tabular}{llll}
\hline SECTOR & REGION & DISTRICT & IGF (GHC) \\
\hline & Ashanti & Adansi South & $234,340.60$ \\
& Central & Atwima Mponua & $212,189.64$ \\
& & Gomoa west & $113,935.92$ \\
SOUTH & Western Region & Amenfi Central & $122,333.77$ \\
& & Sefwi Akontombra & $54,863.49$ \\
& Northern & Kpandai & $23,494.53$ \\
& & Sawla-Tuna-Kalba & $89,222.50$ \\
& Upper East & Talensi & $98,000.00$ \\
& & Nabdam & $60,521.00$ \\
NORTH & Upper west & Wa West & $81,955.71$ \\
& & Sissala East & $93,727.17$ \\
\hline
\end{tabular}

Sourced from 2015 Composite Budgets of the Various Districts

It can be deduced from table 7 that, districts of the South have higher IGFs than districts of the North. Computations from the table shows that there is an average of GhC 157,924.19 IGF among districts of the south as compared to an average of $\mathrm{GhC} 74,486.82$ among districts of the North. However, IGF does not have a statistically significant influence on infrastructure availability in the districts even though a positive correlation exists between the two. A 2-tailed Pearson correlation revealed a $P$ value of $.191(P=.191)$, with a correlation coefficient of .405 . The insignificant influence of IGF on infrastructure availability in the district is due to the fact that, most districts do not spend this fund on infrastructural projects such as building of schools, health facilities, roads, etc. but they rather spend it on administrative costs. In their composite budgets, this fund is mostly allocated to 'central administration' in order to meet day to day administrative costs. The Sefwi Akontombra, Sawla, Amenfi Central and Kpandai districts for instance dedicated $100 \%$ of their IGF to central administration in the 2015 fiscal year. Similarly, the Upper Denkyira West and Adansi South districts both in the southern sector of the country dedicated $96.4 \%$ and $87.6 \%$ of their 
IGFs to central administration respectively. On the average, all twelve districts studied allocated $97.1 \%$ of their IGF to central administration. This explains why IGF has no significant influence on infrastructure availability in the districts.

\section{Discussion}

The study revealed that, even though, infrastructural inequalities among the districts are minimal, the traditional north-south dichotomy is still evident. Districts of the South generally have higher infrastructure indices with an almost perfect equality in the distribution of basic infrastructure whiles districts of the North generally have lower infrastructure indices with more significant inequalities than districts of the South. This situation still reflects Songsore's, (1989) argument that the current regional development trend in Ghana seems to have followed the line of historical regional development left behind by the colonialists hence reflecting the dichotomy in Ghana's spatial economy. Songsore (1989) argued that, different policies pursued in northern and southern Ghana by the colonial administration ensured that, the south had a concentration of manufacturing and other economic activities relative to the north, a situation which made the northern sector a labor reserve for the south. This eventually resulted in a distortion in the internal patterns of production, and the spatial organization of economic and social activity which deepened inequalities between the north and south. This study has shown that, people in the south are more engaged in manufacturing activities than people in the north. Data obtained from the 2010 population and housing census district analytic reports of the study districts for instance showed that, on the average, districts of the South have a higher proportion (6.4\%) of people who are 15 years and older engaged in manufacturing activities than districts of the North which have an average of $4.8 \%$ of the same group of people engaged in manufacturing. Districts of the North are also predominantly more agrarian than districts of the South. Deduced from the district analytic reports, districts of the North have an average of $82.7 \%$ of their populace who are 15 years and older engaged in agriculture whereas districts of the South have an average of $71.8 \%$. Poku-Boansi and Amoako (2015), argued that, many rural regions and communities that only offer agricultural and primary opportunities limit the productive capacities of their people. The poor endowment of these rural regions' socioeconomic opportunities coupled with traditional methods of production leads to continuous stagnation or retrogression of the local economy.

The foregoing suggests that, decentralization does not directly translate into a balanced regional development. This is because there are certain factors in every region which promote the growth of these regions and decentralization either facilitate or mitigate regional disparities based on these factors. Poku-Boansi and Amoako (2015) for instance argued that, a major factor responsible for spatial inequalities is economic, manifested in trade and the movement of people, goods and services. Lessmann (2011) also concluded that the direction of the effect of decentralization depends on the level of economic development. This suggest that, decentralization does not have a direct causal relationship or effect on regional inequalities. However, Poku-Boansi and Amoako (2015), noted that even though, economic growth could lead to regional inequalities, recent evidence suggests that this is not necessarily so, but rather the inability of governments and other relevant actors to design and implement 
the appropriate development interventions. Creation of districts would thus need to be accompanied by appropriate development interventions in order to promote a balanced regional growth.

The study has also shown that the availability of basic infrastructure is not dependent on the IGF of a district. This is because districts dedicate almost their entire IGFs to meeting day to day administrative costs rather than funding infrastructure projects. A possible reason for this, is the delay in the release of the DACF (Nai, 2014) which is the principal source of government funding for Districts Assemblies. Since administrative costs are incurred on daily basis, a readily available source of funds needs to be in place in order to meet such costs. IGF is mobilised internally and controlled by the district assemblies, which makes it a more reliable source of funding for administrative purposes than the DACF. With regards to population, it can be deduced that areas higher populations have higher infrastructure availability. The study has shown that, districts of the South, which are generally more populated than districts of North, have higher CIIs than the districts of the North.

\section{Conclusion and Recommendations}

Districts are the lowest administrative bodies in Ghana through which government, non-governmental and private sector organizations deliver infrastructure facilities and social services to the populace. The creation of districts has thus been one major strategy that politicians use in canvassing votes often with the assertion that it will help to resolve the regional development disparities in the country. Apparently, this study has shown that minimal levels of inequalities exist among the districts studied. The traditional north-south divide in the country is however still evident with regards to the distribution of basic infrastructure among districts in the two sectors. Based on the results of the study, the following recommendations are made:

- While decentralization is necessary to achieve balanced regional development, it needs to be accompanied by the implementation of appropriate development interventions. Government and other bodies responsible for policy formulation in this regard should therefore focus on the design and implementation of programmes that will increase the share of manufacturing and other industrial activities especially in the Northern Districts in order to facilitate the transfer of other investment opportunities from the South which will facilitate the growth of the Northern sector at large. With the largest share of its populace engaged in agriculture, setting up agricultural related industries can serve this purpose.

- Even though, the results of this study have shown that, overall, minimal levels of inequalities exist among all the districts, further research is needed to solidify this finding. Indicators used in this study were mainly selected due to the fact that data was readily available on them across all the selected districts. Hence, this might have resulted in a bias towards better-off districts since it is generally argued that wealthy or well-developed regions are better-off with data availability than less developed regions. Dogan (1994) for instance concluded that, the lower the level of development, the lower the validity of quantitative data. Hence, the unselected districts for this study might be the worse-off districts in their respective regions. Also, due to the difficulty in obtaining data, other important sectors of 
infrastructure such as roads, telecommunications, security among others have not been included. Further research of this sort is thus needed to encompass these sectors and if possible use different sets of indicators for the same infrastructure sectors used in this study in order to affirm the levels of inequality unveiled between the districts.

\section{References}

Adu-Brenya, I. (1999). Spatial development disparities in Ghana, a review of decentralisation as a remedial measure. Masters Degree thesis submitted to the Board of Postgraduate Studies, Kwame Nkrumah University of Science and Technology, Kumasi.

Alam, I. (2011). Infrastructural Development of Towns in Murshidabab: An assessment of Levels of Urbanization. PhD Thesis submitted to Department of Geography, Visva-Bharati University, Santiniketan.West Bengal, India.

Aryeetey, E., Owusu, G., \& Mensah, J. E. (2009). An Analysis of Poverty and Regional Inequalities in Ghana. Global Development Network Working Paper Series. Working Paper 27(7).

Asoka, G. W., Thuo, A. D., \& Bunyasi, M. M. (2013). Effects of population growth on urban infrastructure and services: A case of Eastleigh neighborhood Nairobi, Kenya. Journal of Anthropology and Archaeology, 1(1), 41-56.

Crawford, G. (2003). Democratic Decentralization in Ghana: Issues and Prospects. Paper for Norwegian Association for Development Research.

Dogan, M. (1994). Use and misuse of statistics in comparative research. Limits to Quantification in Comparative Politics: The Gap between Substance and Method. Dogan, Mattei/Kazancigil, Ali (Hrsg.), 35-71.

Escobal J., \& Torero M. (2005). Adverse geography and differences in welfare in Peru. In R. Kanbur and A. J. Venables (Eds), Spatial Inequality and Development. Oxford University Press.

Ghana Statistical Service. (2015). Ghana Poverty Mapping Report. Government of Ghana.

Kim, S. (2008). Spatial Inequality and Economic Development, Theories, Facts, and Policies. The International Bank for Reconstruction and Development, Washington.

Lall, S., \& Chakravorty, S. (2004). Industrial Location and Spatial Inequality: Theory and Evidence from India. World Institute for Development Economics Research, United Nations University.

Lessmann, C. (2009). Fiscal Decentralization and Regional Disparity: Evidence from Cross-section and Panel Data. Environment and Planning A, 41(10), 2455-2473.

Lessmann, C. (2011). Regional Inequality and Decentralization- An Empirical Analysis. Technische Universitat Dresden. 


\section{Macrothink}

International Journal of Regional Development

ISSN 2373-9851 2018, Vol. 5, No. 1

Nai, A. N. A. (2014). DACF and Decentralization Objective. In Republic of Ghana. (2014). The Common Fund Newsletter. District Assembly Common Fund (DACF).

Oates, W. E. (1972). Fiscal Federalism. New York: Harcourt Brace Jovanovich

Poku-Boansi, M., \& Amoako, C. (2015). Dimensions of spatial inequalities in Ghanaian cities. Journal of Geography and Regional Planning.

Pradhan, R. (2007). Does Infrastructure Play Role in Urbanization: Evidence from India. Indian Journal of Economics and Business, 6(1), 81-92

Prud'homme, R. (1995). The Dangers of Decentralization. World Bank Research Observer, 10(2), 201-220.

Rodriguez-Pose, A., \& Gill, N. (2004). Is There a Global Link between Regional Disparities and Devolution? Environment and Planning A, 36(12), 2097-2117.

Songsore, J. (1989). The Spatial Impress and Dynamics of Underdevelopment in Ghana. In Swindell, K., Baba, J.M., Mortimore M. J. (Eds.), Inequality and Development: Case Studies from the Third World. Macmillan Publishers, London.

Tiebout, C. M. (1956). A Pure Theory of Local Expenditures. The Journal of Political Economy, 64(5), 416-424.

UN-HABITAT. (2008b). The State of African Cities, A Framework for addressing Urban Challenges in Africa. Nairobi, Kenya. United Nations Human Settlements Programme.

\section{Copyright Disclaimer}

Copyright for this article is retained by the author(s), with first publication rights granted to the journal.

This is an open-access article distributed under the terms and conditions of the Creative Commons Attribution license (http://creativecommons.org/licenses/by/3.0/). 